\title{
Developing an educational framework for using mobile learning during the era of COVID-19
}

\author{
Khadija Alhumaid $^{\mathrm{a}^{*}}$ \\ ${ }^{a}$ Zayed University, United Arab Emirates \\ C H R O N I C L E \\ Article history: \\ Received: March 15, 202 \\ Received in revised format: April \\ 12,2021 \\ Accepted: June 23, 2021 \\ Available online: June 23, 2021 \\ Keywords: \\ COVID-19 \\ Expectation-Confirmation Model \\ Fear \\ m-Learning \\ Technology Acceptance Model \\ Theory of Planned Behavior
}

\begin{abstract}
A B S T R A C T
This paper focuses on the impact of fear emotion upon technology adoption by educators and students during Covid-19 pandemic. Mobile learning (m-learning) has been applied as the educational social platform within higher education institutes, public as well as private. The research hypotheses were associated with the Covid-19 influence on m-learning adoption with the rise of the coronavirus increasing types of fear. Such fears include fear caused by the education failure, family lockdown, and loss of social relationships. Teachers and students are mostly fearful of these aspects of the situation. An integrated model was established within the research, using theoretical models; the Planned Behavior theory, the Technology Acceptance Model, and the Expectation-Confirmation Model. The proposed integrated model (using PLS-SEM software) was analyzed using an online survey data, with 420 respondents from Zayed University, UAE. The findings indicated that attitude was the best predictor for using the m-learning system, followed by continuous intention, expectation confirmation, perceived usefulness, ease-of-use, perceived fear, behavioral control, and satisfaction. According to the research, during the coronavirus pandemic, if the m-learning system is adopted for educational reasons, the learning and teaching outcome proves quite promising. Yet there is a fear of the family being stressed, or of loss of friends, and also a fear of the results of future schooling. It is therefore necessary to assess the students efficiently during this pandemic so that the situation can be managed emotionally.
\end{abstract}

\section{Background}

Several efforts have been made by universities and colleges to establish a virtual teaching environment using appropriate platforms and resources (Salloum \& Shaalan, 2021; Alhashmi, Salloum, \& Abdallah, 2020; Alshurideh, Salloum, Al Kurdi, Monem, et al., 2019; Hantoobi et al., 2021; Salloum, Mhamdi, et al., 2018; Sultan et al. 2021). These educational institutions are constantly struggling to attain specific outcomes. Yet, due to COVID-19, the institutions are challenged (Alameeri, Alshurideh, \& Al Kurdi, 2021; Amarneh et al., 2021; Al Khasawneh et al., 2021; Leo et al., 2021). Negative emotions have taken rise in the form of fears, worries and apprehension among students worldwide (Alameeri et al., 2020; Alshurideh et al., 2021; Alyammahi et al., 2020; Al Kurdi et al., 2021). The psychological well-being of students is influenced by fear of situations arising that will cause stigma. Covid-19 period has deteriorated and various psycho-social issues that have arisen e.g., discrimination and loss (Ahorsu et al., 2020; Al-Maroof, Alhumaid, Akour, et al., 2021; Lin, 2020; Pappas et al., 2009). Educational institutions have also been affected by fear, creating a hindrance to the learning and teaching process which deeply influences the e-learning process (Al-Maroof et al., 2021; Bettayeb, Alshurideh, \& Al Kurdi, 2020; Turki, 2020). There are various forms of fear such as insecurity, missing out, failure and risk taking (Alt and Boniel-Nissim, 2018; Ellahi, 2017; Machů and Morysová, 2016; Morchid n.d.). Keeping the above-mentioned aspects in mind, it has been observed that fear could affect technology adoption. Various institutions have implemented online learning systems so that the dangerous and malicious influence of coronavirus can be reduced. Yet various colleges and universities are facing challenges related to 
teachers' knowledge of technology and their implementation ability. The ability of students to understand and the inability to convert from a normal class to a virtual class are also issues (Chen \& Li, 2011; Li et al., 2018; Liang, Zheng, \& Wang, 2011). The technology-effectiveness endorsement and the virtual classes depend mostly on technology adoption, considering this as an online learning resource (Akour et al., 2021; Alshamsi et al., 2020; Alshraideh, Al-Lozi, \& Alshurideh, 2017; Alshurideh et al., 2015; Al Kurdi et al., 2020).

Some adoption research indicates that the adoption procedure is not easy as several aspects are affected, such as strategy, context (Salloum, Al-Emran, \& Shaalan, 2016) and learning technology (Alshurideh, Salloum, Al Kurdi, \& Al-Emran, 2019; Salloum et al., 2020; Salloum, Maqableh, et al., 2018). Since technology adoption has been researched by various researchers, it has been observed that, within extraordinary circumstances, innovative teaching methods are adopted, such as the m-learning application (AlSuwaidi et al., 2021; Nuseir et al., 2021; Suleman et al., 2021). However, until now, the coronavirus pandemic has not been assessed. M-learning platforms have been provided by Apple Store and Google Play for users and, through the Store, it is possible to download and update the application. The App Store extends a freemium strategy which positively influences the number of users (Liu, Au, \& Choi, 2014; McIlroy, Ali, \& Hassan, 2016). Much attention must be given to the psychological stance of teachers and learners in relation to the importance of using m-learning in unforeseen time. In Covid19 situation, such a platform has been developed recently, which is why there has been little focus on the domain of higher education. Much research has examined the technology adoption. Yet, little is known about fear of the application adoption during this pandemic. Several studies have considered the technological developments, but not the psychological aspects. The role played by fear has not been understood clearly, which is why the opportunities to make use of technology in terms of education has not been completely understood (Agha, Alzoubi, \& Alshurideh, 2021; Alzoubi, Alshurideh, and Ghazal, 2021; Naqvi et al., 2021). Considering the limitations mentioned above, the present research aims to establish an effective educational assessment of the type of technology that is most suitable even if fear is a dominant part of students' and teachers' lives. The new application is being followed by teachers and students for the first time, so that they may enhance their learning outcomes at this difficult time.

Academically, the literature suggests that the Technology Acceptance Model (TAM), Expectation-Confirmation Model (ECM) and Theory of Planned Behavior (TPB) are successfully applied as the technology adoption model to measure the motivation of users to understand (Liu, Geertshuis, \& Grainger, 2020; Sami Alkalha et al., 2012; Tsai et al., 2020). Therefore, this current research is based on the TAM, TPB and ECM and adding two external elements: subjective norms and fear. This would help to assess the willingness of students to use m-learning systems. Two groups, students and teachers, maintain perceptions related to m-learning use during the pandemic, which would be analyzed using the TAM.

Previously, there has been no research carried out on the aspect of fear during the COVID-19 predicament and its association with the hybrid model (TAM, TPB, and ECM). The current model would analyze the various kinds of fear experienced by teachers and students during the period of the pandemic. Thus, we expect that our study will enhance the educational and technological input for teachers and application developers to understand the implementation method and to establish new technologies during the pandemic lockdown time.

The m-learning adoption conditions during the pandemic need to be understood as this would help to extract various educational aspects that are extraordinary in nature, and which would arise during such unique circumstances. The technology adoption field would be contributed, practically and theoretically.

\section{Literature review}

Earlier adoption research has analyzed the various kinds of fear. For example, anxiety is an essential factor within a certain section of research assessing technology adoption and anxiety. In the educational sector, anxiety is considered as an extraordinary aspect, which influences technology acceptance amongst students. Furthermore, apart from anxiety, if experience and skills are lacking, then this would limit interest in technology usage even further. Another factor present is fear of the actual use of technology. This integrates with literacy and anxiety to decrease technology adoption effectively. Hence, it is essential for educators and teachers to assess the psychological context and make sure that the students are well prepared to accept technology. In the educational sector, another cause of fear is limited preparedness and limited technical abilities. These two factors negatively influence the adoption / acceptance of technology (Callum \& Jeffrey, 2014; Nchunge, Sakwa, \& Mwangi, 2012; Thatcher \& Perrewe, 2002). The fear of technology adoption is limited not only in the educational sector but also within the rest of the (Al-Dhuhouri et al., 2021; Al-Maroof, Alshurideh, et al., 2021; Alkitbi et al., 2021; Almazrouei et al., 2021; AlShehhi et al., 2021; Mehrez et al., 2021). In the health sector, health anxiety is present amongst patients, which leads to fear or apprehension of outcomes that show significant illness. The medical-sector research, therefore, stresses the negative influences of anxiety and perceived risk when technology is being used (Aburayya et al., 2020; Alhashmi, Salloum, and Mhamdi, 2019; Almansoori et al., 2021; Kamal, Shafiq, \& Kakria, 2020; Meng et al., 2020; Mouzaek et al., 2021; Salloum et al., 2017). In the banking sector (Al-Khayyal et al. 2020; Alsuwaidi et al. 2021), various kinds of fear arise from attitudes towards, as well as perceptions of, technology (Al-Maroof, Alfaisal, \& Salloum, 2020; Alsharhan, Salloum, \& Shaalan, n.d.; Gaid \& Salloum, 2021). Within the context of mobile payments (Alshurideh, Al Kurdi, \& Salloum, 2021; Salloum et al., 2019; Salloum \& Al-Emran, 2018), numerous consumers are afraid to present their data. Research also indicates that customers fear 
they may be subject to fraud. In any household, it is found that when technology is feared, there is also a lack of interest in technology use, giving rise to family tasks. Lastly, mobile banking technology is also negatively influenced by lack of trust and experience (Ahmed et al., 2021; AlGhanem et al., 2020; Bailey et al., 2020; Makttoofa, Khalidb, \& Abdullahc, n.d.).

Several studies have assessed technology acceptance and the fear issue. Many of these studies have relied on the TAM model (Alshurideh, Al Kurdi, \& Salloum, 2020; Bailey et al., 2020; Bhattacherjee \& Hikmet, 2007; Callum \& Jeffrey, 2014; Kamal, Shafiq, \& Kakria, 2020; Makttoofa, Khalidb, \& Abdullahc, n.d.; Mhamdi, Al-Emran, \& Salloum, 2018; Nchunge, Sakwa, \& Mwangi, 2012; Al Suwaidi et al., 2021) and on other models (Aburayya et al., 2020; Al-Maroof et al., 2020; Al-Maroof, Alhumaid, Alhamad, et al., 2021; Al-Maroof et al., 2019; Alghizzawi et al., 2018; Alshurideh, 2018; Brown and Venkatesh, 2005; Elbasir et al., 2021; Habes et al., 2019; Johnston and Warkentin, 2010; Al Kurdi, Alshurideh, and Salloum, 2020; Meng et al., 2020; Salloum et al., 2021; Thatcher and Perrewe, 2002). The objective of these studies is to assess the influence of technology acceptance based on the fear of technology. There are various justifications provided by people as to why they fear using technology. Some stated that it was a lack of confidence. When a human functions, it is possible that he will make mistakes, which is why the fear factor is amplified (Gresham, 2020). On the other hand, some claim that when technology has not been used, the process consumes more time and tasks remain unaccomplished within the allotted time (Appavoo, 2020). Some acceptance studies state that there is a fear that data privacy will be breached, which is why so much focus is placed on privacy and on security awareness (Distler, Lallemand, \& Koenig, 2020).

\subsection{Knowledge gap}

The current research carries out a bibliometric mapping analysis on the mobile learning technology literature so that the research gap presented in Fig. 1 can be addressed.

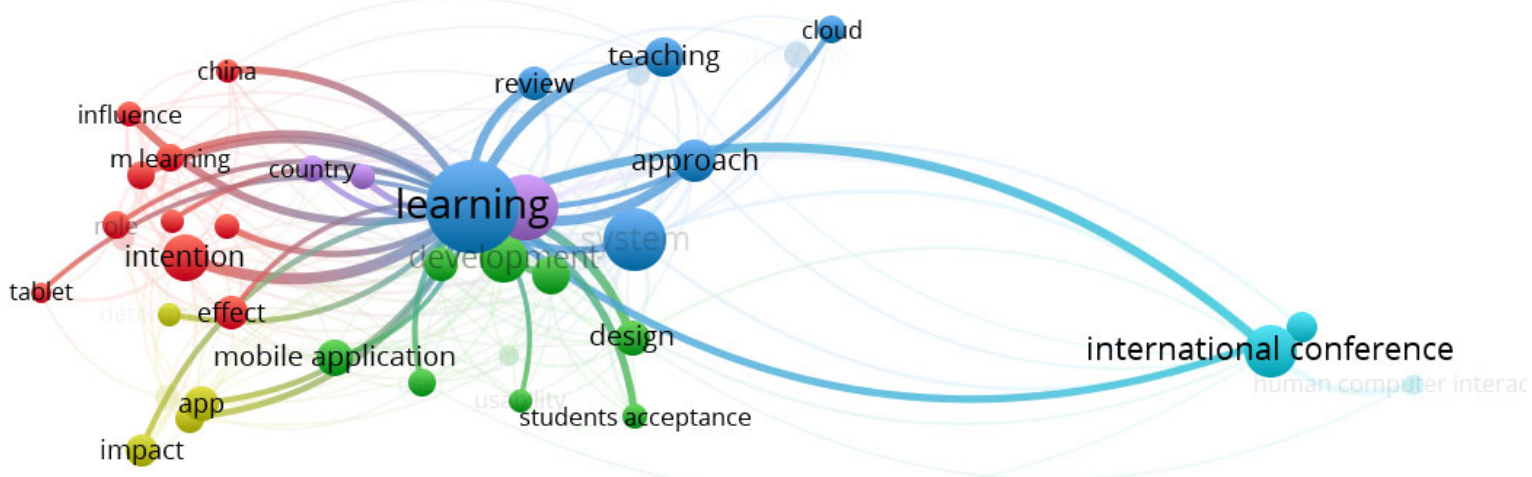

Fig. 1. Most used author keywords in mobile learning adoption/acceptance

The database has been searched as follows: "ACM Digital Library, Google Scholar, IEEE, SAGE Pub, ScienceDirect, and Springer". This was during the time period 2015-2020 in which nearly 1,393 papers made use of the keywords "mobile learning", "mobile learning adoption", and "mobile learning acceptance". The numbers were distributed in the following manner: ACM Digital Library engine search with 99 papers on mobile learning; 708 papers found in a Google Scholar engine search; 210 papers found in IEEE; SAGE Pub engine with about 65 articles; ScienceDirect with 147 papers; and 164 articles in the Springer engine. It is necessary to consider that various studies have assessed mobile learning adoption or acceptance. However, a few studies have addressed m-learning usage during the COVID-19 outbreak. There are 25 articles in total. Within the field, the earliest paper found was in the 2020 databases (Raza et al., 2020). This paper is the earliest and has then provided an entirely new procedure to create real information in m-learning during COVID-19. This was the first step in m-learning technology development in which scientists remained focused on those mobile devices which have an earphone, a front camera and signal processing units. Some earlier research studies have focused on mobile devices, as well as on mobile learning platforms. Out of these research studies, one considered mobile learning technology adoption and extracted the specific features motivating individuals to adopt smartphones. For functionality, the hands-free phone is highly influential (Adapa et al., 2018). The users become quite involved in using the smartphones. Furthermore, using the internet, the information can be quickly accessed, which is why time is saved and the adoption level rises. The adoption issue was considered by using a personal perspective. According to the research, if personal features, such as readiness and openness, are present, new experiences may happen and it is quite possible that the device may be adopted since there is a high perceived-usefulness level present for the device. Finally, the research by (Gasaymeh \&Waswas, 2019) indicates that users positively consider the use of smartphones because of its ease of use and usefulness. However, fear has been raised by the research, along with the health concern brought forward by the users. Details of the research studies focusing on mobile technology acceptance are mentioned 
below and the coronavirus, or COVID-19 pandemic, is included. The research has considered mobile learning acceptance since mobile learning is believed to be a technology that is unfamiliar in the Middle East. There are some students who consider its importance within the educational context. Hence, the current research would motivate educators, teachers and students in the future to use it within various educational environments.

\section{Research model}

The research model that has been developed is based upon integration of the subjective norm and the fear construct with three kinds of theoretical models: TAM, TPB, and ECM. The proposal made is that the subjective norm (SBJ) and perceived fear (PF) would significantly influence the m-learning system's perceived ease of use (PEU) and usefulness (PU). Additionally, regarding attitude (ATD), subjective norm (SBJ), and perceived behavioral control (PBC), they would affect the continuous intention $(\mathrm{CON})$ to use m-learning systems (CON). It must also consider that CON influences the actual use (ACU) of mlearning perception (Fig. 2).

\subsection{Perceived Fear $(P F)$}

Some studies suggest that fear can also be perceived positively if there is some sort of real danger, which COVID-19 has. Different forms of fear related to COVID-19 can be highlighted such as uncertainty, health anxiety, and fear of losing loved ones. That is why there are two aspects which need consideration: worrying to a high degree and possibility that are affected by this disease (Ahorsu et al., 2020; Gerhold, 2020). The current research aims to analyze the association with technology adoption using TAM and perceived fear (PF) as an external factor. Hence, the research will try to resolve the issue of TAMmodel limitation (Tarhini, Hone, and Liu, 2015). The influence of PF on the TAM model would be analyzed in terms of PU and PEU, in addition to the SBJ which is also an external factor. Keeping this assumption in mind, the following has been hypothesized:

\section{$\mathbf{H}_{1}$ : PF positively affects the PEU of m-learning. \\ $\mathbf{H}_{2}$ : $P F$ positively affects the $P U$ of m-learning.}

\subsection{The Expectation confirmation (EXP)}

EXP refers to someone's perceptions of the congruence in relation to the actual performance as the EXP is linked to actual performance (Bhattacherjee, 2001). Earlier research states that EXP significantly influences satisfaction (SAT) and the PU of the various mobile technologies (Al-Emran, Arpaci, and Salloum, 2020; Muhammad Alshurideh et al., 2020; Le et al. 2020; Nascimento, Oliveira, and Tam, 2018).

H3: EXP positively affects the PU of m-learning.

$\mathbf{H}_{4}$ : EXP positively affects SAT with m-learning.

\subsection{The TAM}

The external factor validation of personal belief is measured by one fixed goal that is part of the TAM model. This is quite a powerful model which explains that individuals would accept technology if it was present in educational institutions (AlMaroof \& Al-Emran, 2018; Davis, 1989; Teo, 2012; Venkatesh \& Bala, 2008). PU and PEU are dominant features according to TAM which can measure two kinds of perception. Based on the TAM, using a particular system (e.g., m-learning) in our life would be related to the PU that would enhance our job performance (Davis, 1989). Accordingly, PU maintains a significant influence upon the CON to use several mobile technologies (Alshurideh et al., 2020; Joo, Kim, and Kim, 2016; Le et al., 2020; Nascimento, Oliveira, \& Tam, 2018). whereas PEU refers to someone's uses a particular system that needs little effort to use (Davis, 1989). Earlier research indicated that PEU significantly influences the CON to use m-learning (Alshurideh et al., 2020; Joo, Kim, and Kim ,2016; Le et al., 2020; Nascimento, Oliveira, \& Tam, 2018). Keeping the earlier assumption in mind, if users think that technology can be used easily, they will develop positive attitudes towards m-learning. Therefore, their perceptions of this PU are observed. In this way, if technology is perceived as useful, then there is a higher probability that a positive attitude will be maintained towards adopting this technology, highlighting our hypotheses:

H5: PEU positively affects the PU of m-learning.

H6: PU positively affects SAT with m-learning.

$\mathbf{H}_{7}$ : PEU positively affects the CON to use m-learning.

Hs: $P U$ positively affects the CON to use m-learning.

\subsection{Satisfaction (SAT)}

SAT refers to the users' attitude of using a particular system (e.g., m-learning) which they feel satisfied with such a system after usage (Doll, Hendrickson, \& Deng, 1998). Earlier research stated that SAT significantly influenced the CON to use mobile technologies (Alshurideh et al., 2020; Le et al., 2020; Nascimento, Oliveira, \& Tam, 2018; Tam, Santos, \& Oliveira, 2018). 
H9: SAT positively affects the CON to use m-learning.

\subsection{Attitude (ATD)}

ATD refers to someone's perception towards a particular system (Karjaluoto, Mattila, and Pento, 2002). Earlier m-learning studies stated that ATD maintained a relationship with CON. Research stated that ATD have a high influence on CON to adopting m-learning (Al-Emran, Arpaci, \& Salloum, 2020; Cheon et al., 2012; Khanh \& Gim, 2014; Prieto, Migueláñez \& García-Peñalvo, 2014).

$\mathbf{H}_{10}$ : ATD positively affects the CON to use m-learning.

\subsection{Perceived Behavioral Control (PBC)}

The PBC refers to someone's perception and experience of using a particular system in terms of ease or difficulty of performing the behavior of interest (Ajzen, 1991). Research shows that PBC significantly influences the CON to use m-learning (AlEmran, Arpaci, and Salloum, 2020; Cheon et al., 2012; Cheong et al., 2012; Kim, 2010). Hence, the following is attained.

H11: PBC positively affects the CON to use m-learning.

\subsection{Subjective norm (SBJ)}

SBJ is a means that helps measure someone's perception in the presence of other individuals who share a similar attitude and who would (not) exhibit similar behavior towards technology. Socially, the TAM model has been strengthened by the SBJ since it helps the TAM to account for users' behavior when looking at various users (Fishbein \& Ajzen, 1975). We perceive SBJ as the external factor that manages students' CON to accepting the m-learning system. Furthermore, PBC is influenced by SBJ, especially in the case of PU or PEU, which are applied in the literature research in an extensive manner regarding technology adoption or acceptance (Song \& Kong, 2017; Venkatesh \& Bala, 2008; Viswanath Venkatesh \& Davis, 2000; Wong, Teo, \& Russo, 2012). One item of recent research by (Huang, Teo, and Zhou 2020) used external factors TAM and SBJ, in which emphasis was placed on the association between the external factors and the rest of the included TAM factors for various earlier items of research. Yet it has been observed that the external SBJ factor would not be implemented in an effective or a deep manner within the research. Research shows that CON is linked to someone using m-learning platforms (Al-Emran, Arpaci, \& Salloum, 2020; Cheon et al., 2012; Liu \& Chen, 2008; Mtebe \& Raisamo, 2014; Park, Nam, \& Cha, 2012).

\section{H12: SBJ positively affects the CON to use m-learning.}

\subsection{The Continuous intention (CON)}

$\mathrm{CON}$ refers to a person's intention to continue using a particular system if they benefit to some extent from it (Bhattacherjee, 2001). Research indicates that CON significantly influences the ACU of m-learning systems (Al-Emran, Arpaci, \& Salloum, 2020; Alshurideh et al., 2020; Joo, Kim, \& Kim, 2016).

\section{$\mathbf{H}_{13}$ : CON positively affects the ACU of m-learning.}

Fig. 2 revealed our proposed model. The theoretical model has been presented as the structural equation model and would be analyzed with the help of machine learning methods.

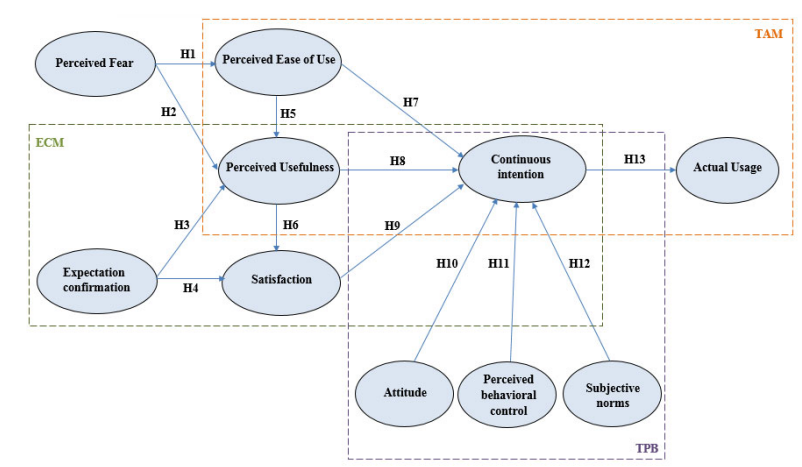

Fig. 2. The study model 


\section{Method}

\subsection{Data collection}

Data were collected between October $25^{\text {th }}$ and December $25^{\text {th }} 2020$ (fall semester), after carrying out online surveys which helped to target UAE university students. Target universities provided ethical clearance for this research. The research objective and survey links were emailed to the related students. The response rate was maximized by sending the survey link through the university's social media platforms. 500 questionnaires were handed out randomly by the student department and 420 questionnaires were replied, indicating an 84 percent response rate. There were some missing values, which is why 80 completed questionnaires were rejected. Hence, 420 questionnaires were considered by the survey team since these were complete and effective. Only students were included since it is believed that it is the students who are highly influenced by the research effectiveness. If the technology is insufficient to support the students, the colleges and universities can replace the tool. If the teachers have significant experience, they can easily adopt these technologies, unlike the students. Even though the students have knowledge regarding the application through social media, they have not had the chance to use it on their own. Krejcie \& Morgan (Krejcie \& Morgan, 1970) stated that the sample size estimated for the 1500 is 306 respondents. As compared with the trivial criteria, the 420 -sample size is considerably higher.

\subsection{Demographic data}

Table 1 presents the sample demographic feature. The ratio of female to male students is $61 \%$. A total of $62 \%$ of respondents were aged between 18 and 29 and 38\% were aged over 29. Most respondents have an academic history with university degrees. A total of $77 \%$ have BA, 21\% have MA and 2\% have $\mathrm{PhD}$. (Al-Emran and Salloum, 2017) suggests that a "purpose sampling approach" be applied and the respondents were interested in voluntarily participating in the research. Students from different colleges were included in the sample and their age groups are also diverse.

Table 1

The sample demographic feature

\begin{tabular}{|c|c|c|c|}
\hline Criterion & Indictor & $\mathbf{n}$ & $\%$ \\
\hline \multirow[t]{2}{*}{ Gender } & Female & 255 & $61 \%$ \\
\hline & Male & 165 & $39 \%$ \\
\hline \multirow[t]{4}{*}{ Age } & $18-29$ & 261 & $62 \%$ \\
\hline & $30-39$ & 97 & $23 \%$ \\
\hline & $40-49$ & 62 & $15 \%$ \\
\hline & $50-59$ & 0 & $2 \%$ \\
\hline \multirow[t]{3}{*}{ Education qualification } & $\mathrm{BA}$ & 322 & $77 \%$ \\
\hline & MA & 88 & $21 \%$ \\
\hline & $\mathrm{PhD}$ & 10 & $2 \%$ \\
\hline
\end{tabular}

\subsection{The instrument}

The research instrument is divided into two parts. First, the participant demographic data. Second, responses related to the conceptual model variables (29 items) were collected. Items from (Al-Emran, Arpaci, \& Salloum, 2020; Davis, 1989) were used to assess the PEU and PU. Items from (Al-Emran, Arpaci, \& Salloum, 2020; Bhattacherjee, 2001) were used to extract the items for analysis of EXP, SAT, and CON. SBJ items were used from (Al-Emran, Arpaci, \& Salloum, 2020; Viswanath Venkatesh et al., 2003), but the actual-use indicators have been adopted using (Al-Emran, Arpaci, \& Salloum, 2020; Mohammadi, 2015). Table 2 illustrates the constructs and its related items.

\section{Table 2}

Constructs and their sources

\begin{tabular}{|c|c|c|}
\hline Constructs & $\begin{array}{l}\text { Number of } \\
\text { items }\end{array}$ & Source \\
\hline Actual use (ACU) & 2 & (Al-Emran, Arpaci, and Salloum 2020; Mohammadi 2015) \\
\hline Attitude (ATD) & 3 & $\begin{array}{l}\text { (Al-Emran, Arpaci, and Salloum 2020; Cheon et al. 2012; Khanh and Gim 2014; Prieto, } \\
\text { Migueláñez, and García-Peñalvo 2014) }\end{array}$ \\
\hline Continuous intention $(\mathrm{CON})$ & 3 & (Al-Emran, Arpaci, and Salloum 2020; Bhattacherjee 2001) \\
\hline Expectation confirmation (EXP) & 3 & (Al-Emran, Arpaci, and Salloum 2020; Bhattacherjee 2001) \\
\hline Perceived usefulness (PU) & 3 & (Al-Emran, Arpaci, and Salloum 2020; Davis 1989) \\
\hline Perceived ease of use (PEU) & 3 & (Al-Emran, Arpaci, and Salloum 2020; Davis 1989) \\
\hline Perceived behavioral control (PBC) & 3 & (Al-Emran, Arpaci, and Salloum 2020) \\
\hline Perceived fear $(\mathrm{PF})$ & 3 & (R.S. Al-Maroof et al. 2020) \\
\hline Subjective norm (SBJ) & 3 & $\begin{array}{l}\text { (Ahmad Aburayya and Salloum n.d.; Al-Emran, Arpaci, and Salloum 2020; Viswanath } \\
\text { Venkatesh et al. 2003) }\end{array}$ \\
\hline Satisfaction (SAT) & 3 & (Al-Emran, Arpaci, and Salloum 2020; Bhattacherjee 2001) \\
\hline
\end{tabular}


Questionnaire-item reliability was tested through a pilot study. There were nearly 50 students out of 500 taking part in the pilot research, randomly picked from the population decided upon. The main results include the pilot research, in which pilot participants have been included within the main research; however, new data was extracted from these individuals. The pilot study's internal reliability was tested through the Cronbach alpha test and this showed acceptable results related to the measurement items. When such an analysis trend is observed within the research studies (Al-Maroof et al., 2021; Nunnally, 1978; Salloum, n.d.), it is acceptable to have 0.7 as the reliability coefficient. The Cronbach alpha values are presented in Table 3 for the next stated seven measurement scales.

Table 3

Cronbach's alpha test

\begin{tabular}{ccccc}
\hline Items & CA ( $\geq \mathbf{0 . 7 0 )}$ & Items & CA ( $\geq \mathbf{0 . 7 0 )}$ & \\
ACU & 0.847 & PEU & \\
ATD & 0.879 & PBC & \\
CON & 0.775 & PF & 0.715 \\
EXP & 0.769 & SBJ & 0.847 \\
PU & 0.758 & SAT & 0.868 \\
\hline
\end{tabular}

\subsection{Common method bias (CMB)}

To ensure that there was no CMB in the collected data, the Harman's single-factor is applied, using 10 variables (ACU, ATD, CON, EXP, PU, PEU, PBC, PF, SBJ, SAT) (Podsakoff et al., 2003). One factor was loaded with the 10 factors. Accordingly, the largest variance present (23.21\%) is lower than the 50\% threshold value (Podsakoff et al., 2003). Therefore, there are zero concerns present regarding collected-data CMB.

\section{Findings}

The PLS-SEM was used to analyze the data. It was accompanied by the SmartPLS V.3.2.7 program (Ringle, Wende, and Becker, 2015). A two-stage assessment approach was implemented for collected data evaluation, along with the structural model and the measurement model (Hair et al., 2017). There are various explanations for the PLS-SEM within the analysis.

First, PLS-SEM has been used since it is most appropriate for the research if it has been based on an earlier one (Urbach \&Ahlemann, 2010). Second, exploratory research that includes complex models should make use of PLS-SEM (Hair Jr et al., 2016). Third, the entire model is analyzed by PLS-SEM as a single unit and is not broken into parts (Goodhue, Lewis, \&Thompson, 2012). Measurement is carried out through a concurrent analysis with the help of PLS-SEM, along with the structural model, which is why calculations are expected to be accurate (Barclay, Higgins, \& Thompson, 1995).

\subsection{Convergent validity}

Hair et al. (2017) considers that construct reliability and validity must be observed for the measurement model evaluation. In this case, it includes composite reliability (CR), Dijkstra-Henseler's rho (pA), and Cronbach's alpha (CA) and validity includes convergent and discriminant validity (DV). According to Table 4, CA values were higher than the 0.7 threshold value and would lie within the 0.730 to 0.887 range, helping to state the construct's reliability. The CR ranges 0.734 to 0.890 and these are higher than the recommended 0.7 (Nunnally and Bernstein, 1994). CR can also be computed using the pA reliability coefficient (Kline 2015). Similar to CA and CR, for the reliability coefficient $\rho$ A, 0.7 or a greater value should be presented for the exploratory research. Values higher than 0.80 or 0.90 should be attained for the $\rho A$ if the research is carried out at an advanced level (Hair, Ringle, and Sarstedt, 2011; Henseler, Ringle, and Sinkovics, 2009; Nunnally and Bernstein, 1994). The measurement construct is able to present the reliability coefficient value or the $\rho$ A which is higher than 0.70 . Based on these tests, verification of construct reliability is possible, stating that there is an accurate construct. After testing the Average Variance Extracted (AVE), convergent validity can be measured and factor loading (Hair et al., 2017). The 0.7 suggested value is lower as compared with the factor-loadings values. Apart from this, the values generated from AVE, 0.594 to 0.796 , are higher than the 0.5 threshold value as stated in Table 4 . Keeping these outcomes in mind, for each construct, it would be efficiently possible to evaluate convergent validity.

\subsection{Discriminant validity}

For the DV measurement (Hair et al., 2017), two parameters should be measured: Fornell-Larker and the Heterotrait-Monotrait ratio (HTMT) factors. The conditions are supported by the Fornell-Larker factor, according to the Table 5 findings, since each AVE value, added to the square root, would exceed the correlation value present with other constructs (Fornell \& Larcker, 1981). The HTMT ratio attained values are shown in Table 6 and these show that 0.85 , the threshold value, is higher than each construct value (Henseler, Ringle, \& Sarstedt, 2015). Hence, there is confirmation for the HTMT ratio. Keeping these 
findings in mind, it is possible to calculate discriminant validity. The data analysis showed that reliability and validity of the measurement model are smoothly assessed. Hence, collected data would be used further and testing done for the structural model.

Table 4

The convergent validity outcomes

\begin{tabular}{|c|c|c|c|c|c|c|}
\hline Constructs & Items & Factor loading & $\mathbf{C A}$ & $\mathbf{C R}$ & PA & AVE \\
\hline \multirow[t]{2}{*}{$\mathrm{ACU}$} & ACU1 & 0.726 & 0.887 & 0.834 & 0.845 & 0.661 \\
\hline & ACU2 & 0.886 & & & & \\
\hline \multirow[t]{3}{*}{ ATD } & ATD1 & 0.846 & 0.840 & 0.890 & 0.886 & 0.789 \\
\hline & ATD2 & 0.805 & & & & \\
\hline & ATD3 & 0.805 & & & & \\
\hline \multirow[t]{3}{*}{$\mathrm{CON}$} & CON1 & 0.819 & 0.869 & 0.822 & 0.837 & 0.700 \\
\hline & CON2 & 0.795 & & & & \\
\hline & CON3 & 0.883 & & & & \\
\hline \multirow[t]{3}{*}{ EXP } & EXP1 & 0.822 & 0.730 & 0.883 & 0.879 & 0.663 \\
\hline & EXP2 & 0.873 & & & & \\
\hline & EXP3 & 0.778 & & & & \\
\hline \multirow[t]{3}{*}{ PU } & PU1 & 0.808 & 0.880 & 0.819 & 0.823 & 0.594 \\
\hline & PU2 & 0.845 & & & & \\
\hline & PU3 & 0.866 & & & & \\
\hline \multirow[t]{3}{*}{ PEU } & PEU1 & 0.872 & 0.870 & 0.857 & 0.850 & 0.644 \\
\hline & PEU2 & 0.832 & & & & \\
\hline & PEU3 & 0.857 & & & & \\
\hline \multirow[t]{3}{*}{ PBC } & PBC1 & 0.878 & 0.856 & 0.861 & 0.836 & 0.796 \\
\hline & $\mathrm{PBC} 2$ & 0.906 & & & & \\
\hline & $\mathrm{PBC} 3$ & 0.848 & & & & \\
\hline \multirow[t]{3}{*}{ PF } & PF1 & 0.795 & 0.845 & 0.803 & 0.815 & 0.756 \\
\hline & PF2 & 0.778 & & & & \\
\hline & PF3 & 0.846 & & & & \\
\hline \multirow[t]{3}{*}{ SBJ } & SBJ1 & 0.805 & 0.801 & 0.734 & 0.746 & 0.771 \\
\hline & SBJ2 & 0.819 & & & & \\
\hline & SBJ3 & 0.795 & & & & \\
\hline \multirow[t]{3}{*}{ SAT } & SAT1 & 0.883 & 0.806 & 0.834 & 0.839 & 0.772 \\
\hline & SAT2 & 0.805 & & & & \\
\hline & SAT3 & 0.819 & & & & \\
\hline
\end{tabular}

Table 5

Fornell-Larcker scale

\begin{tabular}{cccccccccc}
\hline & ACU & ATD & CON & EXP & PU & PEU & PBC & PF & SBJ \\
\hline ACU & $\mathbf{0 . 8 4 4}$ & & & & & & & \\
ATD & 0.452 & $\mathbf{0 . 8 4 0}$ & & & & & \\
CON & 0.355 & 0.529 & $\mathbf{0 . 8 6 7}$ & & & & \\
EXP & 0.536 & 0.452 & 0.503 & $\mathbf{0 . 8 3 8}$ & & & \\
PU & 0.457 & 0.429 & 0.241 & 0.160 & $\mathbf{0 . 8 8 5}$ & & \\
PEU & 0.518 & 0.455 & 0.363 & 0.288 & 0.256 & $\mathbf{0 . 8 8 7}$ & & \\
PBC & 0.326 & 0.399 & 0.454 & 0.428 & 0.476 & 0.521 & $\mathbf{0 . 8 3 8}$ & \\
PF & 0.266 & 0.469 & 0.445 & 0.208 & 0.566 & 0.401 & 0.422 & $\mathbf{0 . 8 0 9}$ \\
SBJ & 0.445 & 0.561 & 0.230 & 0.638 & 0.455 & 0.452 & 0.477 & 0.403 & \\
SAT & 0.408 & 0.400 & 0.319 & 0.588 & 0.250 & 0.608 & 0.257 & 0.428 & 0.466 \\
\hline
\end{tabular}

Table 6

Heterotrait-Monotrait ratio (HTMT)

\begin{tabular}{ccccccccc}
\hline & ACU & ATD & CON & EXP & PU & PEU & PBC & PF \\
\hline ACU & & & & & & & & \\
ATD & 0.430 & & & & & & \\
CON & 0.433 & 0.651 & & & & & \\
EXP & 0.408 & 0.523 & 0.590 & & & & \\
PU & 0.119 & 0.309 & 0.432 & 0.502 & & & \\
PEU & 0.169 & 0.218 & 0.334 & 0.504 & 0.150 & & \\
PBC & 0.280 & 0.202 & 0.205 & 0.329 & 0.150 & 0.219 & & \\
PF & 0.216 & 0.180 & 0.293 & 0.202 & 0.150 & 0.226 & 0.303 & \\
SBJ & 0.268 & 0.339 & 0.432 & 0.403 & 0.150 & 0.382 & 0.290 & 0.501 \\
SAT & 0.123 & 0.240 & 0.600 & 0.505 & 0.150 & 0.200 & 0.133 & 0.404 \\
\hline
\end{tabular}




\subsection{Model fit}

The model fit measures for the SmartPLS are the following. The standard root means square residual (SRMR), exact fit criteria, d_ULS, d_G, Chi-Square, NFI, and RMS theta indicate the model fit in PLS-SEM (Trial n.d.). The observed correlations and model implied correlation matrix (Hair Jr et al., 2016) is stated by the SRMR and values lower than 0.08 are found to be good model-fit measures (Hu and Bentler, 1998). A good model fit is present if the NFI values are over 0.90 (Bentler and Bonett, 1980). For the proposed model, the NFI is a ratio of Chi2 value to the null model or benchmark model (Lohmöller, 1989). If the parameters are large, the NFI would be large, which is why the NPI has not been recommended as the model-fit indicator (Hair Jr et al., 2016). Two metrics squared Euclidean distance d_ULS, and geodesic distance d_G indicate a discrepancy between the empirical covariance matrix and covariance matrix as stated by the composite factor model (Dijkstra and Henseler, 2015; Hair Jr et al., 2016). For reflective models, the RMS theta is applicable and assesses the degree of outermodel residuals correlation (Lohmöller, 1989). If the RMS theta is close to the zero value, the PLS-SEM model is better and there is a good fit if the value remains less than 0.12. If there is anything else, then the fit is lacking (Henseler et al., 2014). According to Hair Jr et al. (2016), a correlation between all constructs can be evaluated through the saturated model and the total effects and model structure are accounted for in the estimated model.

The RMS Theta value was 0.081 indicating that the related goodness-of-fit for the PLS-SEM model was enough to indicate the global PLS-model validity.

Table 7

Model-fit indicators

\begin{tabular}{|c|c|c|}
\hline & \multicolumn{2}{|c|}{ Complete Model } \\
\hline & Saturated model & Estimated model \\
\hline SRMR & 0.033 & 0.042 \\
\hline d_ULS & 0.764 & 1.328 \\
\hline d_G & 0.518 & 0.548 \\
\hline Chi-Square & 454.647 & 463.476 \\
\hline NFI & 0.839 & 0.827 \\
\hline Rms Theta & & \\
\hline
\end{tabular}

\subsection{Testing the Hypotheses}

Our 13 hypotheses were verified using the PLS-SEM approach (Davis, Bagozzi, \& Warshaw, 1992). The $\mathrm{R}^{2}$ value for each path and each hypothesized connection's path significance within the research model was analyzed (Figure 3 and Table 8). The $\mathrm{R}^{2}$ values for adoption of m-learning, ACU, CON, PEU, and PU ranged between 0.496 and 0.681. Hence, there is moderate predictive power present within these constructs (Liu, Liao, \& Peng, 2005).

Table 8

The $\mathrm{R}^{2}$ values

\begin{tabular}{cl}
\hline Constructs & $\mathrm{R}^{2}$ \\
\hline ACU & 0.668 \\
CON & 0.497 \\
PEU & 0.574 \\
PU & 0.496 \\
SAT & 0.681 \\
\hline
\end{tabular}

The empirical data supports all our hypotheses (Table 9).

Table 9

The hypotheses tests

\begin{tabular}{|c|c|c|c|c|c|c|}
\hline $\mathbf{H}$ & Relationship & Path & $t$-value & $p$-value & Direction & Decision \\
\hline $\mathrm{H} 1$ & PF -> PEU & 0.867 & 23.280 & 0.000 & Positive & Supported** \\
\hline $\mathrm{H} 2$ & $\mathrm{PF}->\mathrm{PU}$ & 0.375 & 14.314 & 0.000 & Positive & Supported** \\
\hline $\mathrm{H} 3$ & EXP -> PU & 0.712 & 18.104 & 0.001 & Positive & Supported** \\
\hline $\mathrm{H} 4$ & EXP -> SAT & 0.469 & 5.825 & 0.023 & Positive & Supported* \\
\hline $\mathrm{H} 5$ & PEU -> PU & 0.438 & 5.551 & 0.016 & Positive & Supported* \\
\hline H6 & PU -> SAT & 0.591 & 4.703 & 0.032 & Positive & Supported* \\
\hline $\mathrm{H} 7$ & PEU $->$ CON & 0.688 & 20.448 & 0.000 & Positive & Supported** \\
\hline $\mathrm{H} 8$ & $\mathrm{PU}->\mathrm{CON}$ & 0.642 & 15.598 & 0.000 & Positive & Supported** \\
\hline H9 & $\mathrm{SAT}->\mathrm{CON}$ & 0.759 & 12.190 & 0.002 & Positive & Supported** \\
\hline $\mathrm{H} 10$ & ATD $->$ CON & 0.523 & 7.328 & 0.029 & Positive & Supported* \\
\hline H11 & $\mathrm{PBC}->\mathrm{CON}$ & 0.419 & 5.328 & 0.025 & Positive & Supported* \\
\hline H12 & $\mathrm{SBJ}->\mathrm{CON}$ & 0.653 & 16.698 & 0.000 & Positive & Supported** \\
\hline $\mathrm{H} 13$ & $\mathrm{CON}->\mathrm{ACU}$ & 0.742 & 18.478 & 0.000 & Positive & Supported** \\
\hline \multicolumn{7}{|c|}{$\mathrm{p}^{* *}=<0.01, \mathrm{p}^{*}<0.05$} \\
\hline
\end{tabular}


The findings revealed that PF had impact on PEU $(\beta=0.867, \mathrm{P}<0.001)$ supporting hypothesis $\mathrm{H} 1$, while $\mathrm{PU}$ significantly affected PF $(\beta=0.375, \mathrm{P}<0.001)$; EXP $(\beta=0.712, \mathrm{P}<0.001)$; PEU $(\beta=0.438, \mathrm{P}<0.05)$; SAT $(\beta=0.591, \mathrm{P}<0.05)$, supporting our H2, H3, H5 and H6 respectively. EXP had impact on SAT $(\beta=0.469, \mathrm{P}<0.001)$ indicating H4 is supported. CON was affected by $\mathrm{PEU}(\beta=0.688, \mathrm{P}<0.001) ; \mathrm{PU}(\beta=0.642, \mathrm{P}<0.001)$; $\operatorname{SAT}(\beta=0.759, \mathrm{P}<0.001)$; $\operatorname{ATD}(\beta=0.523, \mathrm{P}<0.05) ; \mathrm{PBC}(\beta=$ $0.419, \mathrm{P}<0.05)$; and SBJ $(\beta=0.653, \mathrm{P}<0.05)$, supporting $\mathrm{H} 7, \mathrm{H} 8, \mathrm{H} 9, \mathrm{H} 10, \mathrm{H} 11$, and $\mathrm{H} 12$ respectively. Finally, CON to use m-learning platform significantly influenced ACU $(\beta=0.742, \mathrm{P}<0.001)$, supporting H13.

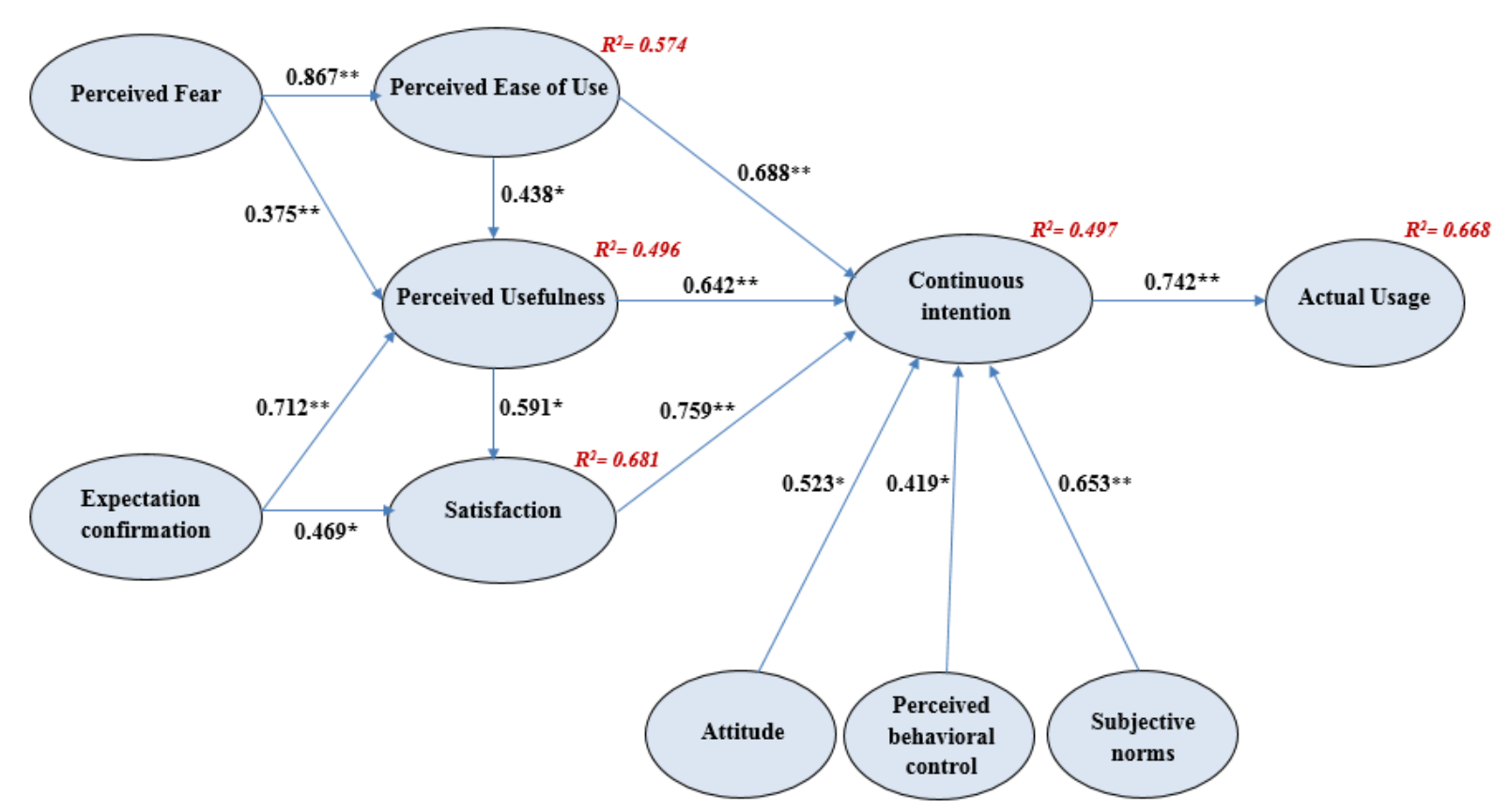

Fig. 3. Hypotheses testing results

\section{Conclusion}

The current research is consistent with early studies in terms of the TAM, TPB and ECM variables' importance (Davis, 1989; Teo, 2012; Venkatesh and Bala, 2008). The PU and PEU present and earlier results are also consistent since it is observed that the PU and PEU highly have impact on the m-learning acceptance of our respondents and place emphasis on the variables related to respondents' intention to use m-learning during the present extraordinary circumstances caused (COVID-19) (Habes et al., 2020). Likewise, the PU was highly affected by the PEU indicating that if someone perceived technology to be easy, then they would adopt it.

For SBJ, our results indicate a significant association between the SBJ and students' acceptance of m-learning, suggesting that students' acceptance of m-learning is highly affected by the behavior, existence, and reaction of classmates within the class using the m-learning. Earlier research (Song and Kong, 2017; Venkatesh and Bala, 2008; Viswanath Venkatesh and Davis, 2000; Wong, Teo, and Russo, 2012) have presented the same kind of relationship between the SBJ and students' acceptance of m-learning. Our respondents were significantly influenced by classmate behavior, which would increase their sense of security and comfort when in classes. This is why their sense of security is higher and their comfort is necessary during the pandemic. Respondents were found to be intrinsically motivated to make use of the m-learning if the same class is shared with other colleagues. Additionally, the PU and PEU variables highly influence the SBJ. Results indicate that mlearning use is promoted by the availability and attitude of instructors and peers. Since it is a tool used for learning during the pandemic, it is perceived as useful and enjoyable, as well as effort-free. The findings are like those in the earlier research (ElGayar, Moran, \& Hawkes, 2011) in which it was stated that peer and instructor feedback significantly affects students' attitudes towards perceived technology effectiveness.

After the spread of COVID-19, the fear factors that took rise indicate that one of these hypotheses is essential. The human population has been significantly influenced by the COVID-19 pandemic and there is a high transmission probability, which is why the lockdown and stay-at-home policies are applied (Zhang et al., 2020). A model has been adopted by the research which may be useful for research in the future after the COVID-19 influence during the pandemic is assessed. Keeping in mind the research results attained, the time of the fear factor is quite evident; however, with the help of the ML, it has been possible to reduce peer and instructor fears. Furthermore, the PF highly influences the PU and PEU. According to the research 
responses, the PF can be seen at the time of the pandemic; however, the m-learning has a high PU and PEU degree which decreased the fear factor and helped respondents to attain their classes on schedule.

\subsection{Research implications}

Our study focused fear on three aspects: Theoretically, using the TAM, TPB and ECM; empirically testing the COVID-19 effect on mobile application users; and analyzing the COVID-19 influence on users' ability to use mobile application and on users' attitudes towards the usefulness of the m-earning platform. Within earlier research, fear has been analyzed from different perspectives such as technology (Bhattacherjee \& Hikmet, 2007). There is an implication that a negative perception would influence PEU and PU in a direct or indirect manner. In this manner, the current implications, and the ones presented by Bhattacherjee and Hikmet, are similar in saying that fear would negatively influence technology use (Bhattacherjee \& Hikmet, 2007). Hence, it is empirically stated that perceived fear during the pandemic would be a significant variable for any model being adopted.

\subsection{Limitations and future research}

Several limitations can be highlighted here. Initially, generalizing the results for the rest of the UAE's higher educational institutions, or for other countries, should be done with caution. This is due to two aspects: 1 . The sample is based on a specific institution; 2. The convenience sampling technique has been applied for the participant selection. For results to be generalized, it is necessary to take these aspects into account. Second, the research sample was only students, suggesting the actual use of m-learning by others should be analyzed.

\subsection{Recommendations}

Based on our results m-learning system is highly recommended in unforeseen time and seen as a potential solution. M-learning availability allows teachers, peers, a sense of security, as well as an instant communication tool considering the contamination status of the city of Abu Dhabi. Compared with other means of communication, there are various advantages to the mobile learning platform. First, the application can be used on any mobile device and smartphones. Second, the links given during each class can be used several times and this allows easy student-teacher communication throughout the day. Finally, students gain higher confidence and minimum fear is experienced.

\section{References}

Aburayya, A., Alshurideh, M., Al Marzouqi, A., Al Diabat, O., Alfarsi, A., Suson, R., ... \& Salloum, S. A. (2020). An empirical examination of the effect of TQM practices on hospital service quality: an assessment study in UAE hospitals. Systematic Reviews in Pharmacy, $11(9), 347-362$.

Aburayya, A., Alshurideh, M., Al Marzouqi, A., Al Diabat, O., Alfarsi, A., Suson, R., ... \& Alzarouni, A. (2020). Critical Success Factors Affecting the Implementation of TQM in Public Hospitals: A Case Study in UAE Hospitals. Systematic Reviews in Pharmacy, 11(10), $230-242$.

Aburayya, A., \& Salloum, S. A. The Effects of Subjective Norm on the Intention to Use Social Media Networks: An Exploratory Study Using PLS-SEM and Machine Learning Approach.

Adapa, A., Nah, F. F. H., Hall, R. H., Siau, K., \& Smith, S. N. (2018). Factors influencing the adoption of smart wearable devices. International Journal of Human-Computer Interaction, 34(5), 399-409.

Agha, K., Alzoubi, H. M., \& Alshurideh, M. T. (2021, June). Measuring Reliability and Validity Instruments of Technologically Driven Cognitive Intrusion Towards Work-Life Balance. In The International Conference on Artificial Intelligence and Computer Vision (pp. 601-614). Springer, Cham.

Ahmed, A., Alshurideh, M., Al Kurdi, B. \& Salloum, S.A. (2021). 1261 AISC Advances in Intelligent Systems and Computing Digital Transformation and Organizational Operational Decision Making: A Systematic Review.

Ahmed, D., Salloum, S. A., \& Shaalan, K. (2021). Knowledge Management in Startups and SMEs: A Systematic Review. Recent Advances in Technology Acceptance Models and Theories, 389-409.

Ahorsu, D. K., Lin, C. Y., Imani, V., Saffari, M., Griffiths, M. D., \& Pakpour, A. H. (2020). The fear of COVID-19 scale: development and initial validation. International journal of mental health and addiction, 1-9.

Ajzen, I. (1991). The theory of planned behavior. Orgnizational Behavior and Human Decision Processes, 50(2), 179-211.

Akour, I., Alshurideh, M., Al Kurdi, B., Al Ali, A., \& Salloum, S. (2021). Using machine learning algorithms to predict people's intention to use mobile learning platforms during the COVID-19 pandemic: machine learning approach. JMIR Medical Education, 7(1), 1-17.

Al-Dhuhouri, F. S., Alshurideh, M., Al Kurdi, B., \& Salloum, S. A. (2020, October). Enhancing our understanding of the relationship between leadership, team characteristics, emotional intelligence and their effect on team performance: A Critical Review. In International Conference on Advanced Intelligent Systems and Informatics (pp. 644-655). Springer, Cham.

Al-Emran, M., Arpaci, I., \& Salloum, S. A. (2020). An empirical examination of continuous intention to use m-learning: An integrated model. Education and information technologies, 25(4), 2899-2918.

Al-Emran, M., \& Salloum, S. A. (2017). Students' Attitudes Towards the Use of Mobile Technologies in e-Evaluation. International Journal of Interactive Mobile Technologies (iJIM), 11(5), 195-202.

Al-Khayyal, A., Alshurideh, M., A1 Kurdi, B., \& Salloum, S. A. (2021). Factors influencing electronic service quality on electronic loyalty in online shopping context: data analysis approach. In Enabling AI Applications in Data Science (pp. 367-378). Springer, Cham. 
Al-Maroof, R. A., Arpaci, I., Al-Emran, M., Salloum, S. A., \& Shaalan, K. (2021). Examining the acceptance of WhatsApp stickers through machine learning algorithms. In Recent advances in intelligent systems and smart applications (pp. 209-221). Springer, Cham.

Al-Maroof, R. S., Alfaisal, A. M., \& Salloum, S. A. (2021). Google glass adoption in the educational environment: A case study in the Gulf area. Education and Information Technologies, 26(3), 2477-2500.

Al-Maroof, R. S., Salloum, S. A., Hassanien, A. E., \& Shaalan, K. (2020). Fear from COVID-19 and technology adoption: the impact of Google Meet during Coronavirus pandemic. Interactive Learning Environments, 1-16.

Al-Maroof, R. A. S., \& Al-Emran, M. (2018). Students Acceptance of Google Classroom: An Exploratory Study using PLS-SEM Approach. International Journal of Emerging Technologies in Learning, 13(6).

Al-Maroof, R., Al-Qaysi, N., Salloum, S. A., \& Al-Emran, M. (2021). Blended Learning Acceptance: A Systematic Review of Information Systems Models. Technology, Knowledge and Learning, 1-36.

Al-Maroof, R. S., Alshurideh, M. T., Salloum, S. A., AlHamad, A. Q. M., \& Gaber, T. (2021, June). Acceptance of Google Meet during the Spread of Coronavirus by Arab University Students. Informatics 8(2), 24.

Al-Maroof, R. S., Alhumaid, K., Alhamad, A. Q., Aburayya, A., \& Salloum, S. (2021). User acceptance of smart watch for medical purposes: an empirical study. Future Internet, 13(5), 127.

Al-Maroof, R. S., Alhumaid, K., Akour, I., \& Salloum, S. (2021). Factors that affect e-learning platforms after the spread of COVID-19: post acceptance study. Data, 6(5), 49.

Al-Maroof, R. S., Salloum, S. A., AlHamadand, A. Q. M., \& Shaalan, K. (2019, October). A unified model for the use and acceptance of stickers in social media messaging. In International Conference on Advanced Intelligent Systems and Informatics (pp. 370-381). Springer, Cham.

Al-Maroof, R. S., Salloum, S. A., AlHamadand, A. Q. M., \& Shaalan, K. (2020). Understanding an Extension Technology Acceptance Model of Google Translation: A Multi-Cultural Study in United Arab Emirates. International Journal of Interactive Mobile Technologies, 14(03), 157-78.

Alameeri, K. A., Alshurideh, M.T., \& Al Kurdi, B. (2021). The Effect of Covid-19 Pandemic on Business Systems' Innovation and Entrepreneurship and How to Cope with It: A Theatrical View. The Effect of Coronavirus Disease (COVID-19) on Business Intelligence, $334,275-88$.

Alameeri, K., Alshurideh, M., Al Kurdi, B., \& Salloum, S. A. (2020, October). The effect of work environment happiness on employee leadership. In International Conference on Advanced Intelligent Systems and Informatics (pp. 668-680). Springer, Cham.

AlGhanem, H., Shanaa, M., Salloum, S., \& Shaalan, K. (2020). The Role of KM in Enhancing AI Algorithms and Systems. Advances in Science, Technology and Engineering Systems Journal, 5(4), 388-396.

Alghizzawi, M., Ghani, M. A., Som, A. P. M., Ahmad, M. F., Amin, A., Bakar, N. A., \& Habes, M. (2018). The impact of smartphone adoption on marketing therapeutic tourist sites in Jordan. International Journal of Engineering \& Technology, 7(4.34), 91-96.

Alhashmi, S. F., Salloum, S. A., \& Abdallah, S. (2019, October). Critical success factors for implementing artificial intelligence (AI) projects in Dubai Government United Arab Emirates (UAE) health sector: applying the extended technology acceptance model (TAM). In International Conference on Advanced Intelligent Systems and Informatics (pp. 393-405). Springer, Cham.

Alhashmi, S. F., Salloum, S. A., \& Mhamdi, C. (2019). Implementing artificial intelligence in the United Arab Emirates healthcare sector: an extended technology acceptance model. International Journal of Information Technology and Language Studies, 3(3), 27-42.

Alkitbi, S.S., Alshurideh, M., Al Kurdi, B., \& Salloum, S.A. (2021). AISC Advances in Intelligent Systems and Computing Factors Affect Customer Retention: A Systematic Review.

Almansoori, A., AlShamsi, M., Salloum, S. A., \& Shaalan, K. (2021). Critical Review of Knowledge Management in Healthcare. Recent Advances in Intelligent Systems and Smart Applications, 99-119.

Almazrouei, F. A., Alshurideh, M., Al Kurdi, B., \& Salloum, S. A. (2020, October). Social Media Impact on Business: A Systematic Review. In International Conference on Advanced Intelligent Systems and Informatics (pp. 697-707). Springer, Cham.

Alshamsi, A., Alshurideh, M., Al Kurdi, B., \& Salloum, S. A. (2020, October). The influence of service quality on customer retention: A systematic review in the higher education. In International Conference on Advanced Intelligent Systems and Informatics (pp. 404-416). Springer, Cham.

Alsharhan, A., Salloum, S., \& Shaalan, K. (2021). The impact of eLearning as a knowledge management tool in organizational performance. Advances in Science, Technology and Engineering Systems Journal, 6(1), 928-936.

AlShehhi, H., Alshurideh, M., Kurdi, B.A., \& Salloum, S.A. (2021). AISC Advances in Intelligent Systems and Computing The Impact of Ethical Leadership on Employees Performance: A Systematic Review.

Alshraideh, A. T. R., Al-Lozi, M., \& Alshurideh, M. T. (2017). The impact of training strategy on organizational loyalty via the mediating variables of organizational satisfaction and organizational performance: An empirical study on Jordanian agricultural credit corporation staff. Journal of Social Sciences (COES\&RJ-JSS), 6(2), 383-394.

Alshurideh, M., Salloum, S. A., Al Kurdi, B., Monem, A. A., \& Shaalan, K. (2019). Understanding the Quality Determinants that Influence the Intention to Use the Mobile Learning Platforms: A Practical Study. International Journal of Interactive Mobile Technologies, 13(11).

Alshurideh, M., Al Kurdi, B., \& Salloum, S. A. (2019, October). Examining the main mobile learning system drivers' effects: A mix empirical examination of both the Expectation-Confirmation Model (ECM) and the Technology Acceptance Model (TAM). In International Conference on Advanced Intelligent Systems and Informatics (pp. 406-417). Springer, Cham.

Alshurideh, M., Salloum, S. A., Al Kurdi, B., \& Al-Emran, M. (2019, February). Factors affecting the social networks acceptance: an empirical study using PLS-SEM approach. In Proceedings of the 2019 8th International Conference on Software and Computer Applications (pp. 414-418).

Alshurideh, M., Bataineh, A., Alkurdi, B., \& Alasmr, N. (2015). Factors affect mobile phone brand choices-Studying the case of Jordan universities students. International Business Research, 8(3), 141-155.

Alshurideh, M., Al Kurdi, B., Abumari, A., \& Salloum, S. (2018). Pharmaceutical Promotion Tools Effect on Physician's Adoption of Medicine Prescribing: Evidence from Jordan. Modern Applied Science, 12(11), 210-222.

. 2020. Predicting the Actual Use of M-Learning Systems: A Comparative Approach Using PLS-SEM and Machine Learning Algorithms. Interactive Learning Environments, 1-15. 
Alshurideh, M. T., Kurdi, B. A., AlHamad, A. Q., Salloum, S. A., Alkurdi, S., Dehghan, A., ... \& Masa'deh, R. E. (2021, June). Factors affecting the use of smart mobile examination platforms by universities' postgraduate students during the COVID 19 pandemic: an empirical study. In Informatics (Vol. 8, No. 2, p. 32). Multidisciplinary Digital Publishing Institute.

Alshurideh, M. T., Al Kurdi, B., \& Salloum, S. A. (2021). The moderation effect of gender on accepting electronic payment technology: a study on United Arab Emirates consumers. Review of International Business and Strategy.

Alsuwaidi, M., Alshurideh, M., Al Kurdi, B., \& Salloum, S. A. (2020, October). Performance appraisal on employees' motivation: A comprehensive analysis. In International Conference on Advanced Intelligent Systems and Informatics (pp. 681-693). Springer, Cham.

AlSuwaidi, S. R., Alshurideh, M., Al Kurdi, B., \& Aburayya, A. (2021, June). The Main Catalysts for Collaborative R\&D Projects in Dubai Industrial Sector. In The International Conference on Artificial Intelligence and Computer Vision (pp. 795-806). Springer, Cham.

Alt, D., \& Boniel-Nissim, M. (2018). Links between adolescents' deep and surface learning approaches, problematic Internet use, and fear of missing out (FOMO). Internet interventions, 13, 30-39.

Alyammahi, A., Alshurideh, M., Al Kurdi, B., \& Salloum, S. A. (2020, October). The impacts of communication ethics on workplace decision making and productivity. In International Conference on Advanced Intelligent Systems and Informatics (pp. 488-500). Springer, Cham.

Alzoubi, H. M., Alshurideh, M., \& Ghazal, T. M. (2021, June). Integrating BLE Beacon Technology with Intelligent Information Systems IIS for Operations' Performance: A Managerial Perspective. In The International Conference on Artificial Intelligence and Computer Vision (pp. 527-538). Springer, Cham.

Amarneh, B. M., Alshurideh, M. T., Al Kurdi, B. H., \& Obeidat, Z. (2021, June). The Impact of COVID-19 on E-learning: Advantages and Challenges. In The International Conference on Artificial Intelligence and Computer Vision (pp. 75-89). Springer, Cham.

Appavoo, P. (2021). Acceptance of technology in the classroom: A qualitative analysis of mathematics teachers' perceptions. In Intelligent System Design (pp. 1-10). Springer, Singapore.

Bailey, A. A., Pentina, I., Mishra, A. S., \& Ben Mimoun, M. S. (2020). Exploring factors influencing US millennial consumers' use of tapand-go payment technology. The International Review of Retail, Distribution and Consumer Research, 30(2), 143-163.

Barclay, D., Higgins, C., \& Thompson, R. (1995). The partial least squares (PLS) approach to casual modeling: personal computer adoption ans use as an Illustration.

Bentler, P. M., \& Bonett, D. G. (1980). Significance tests and goodness of fit in the analysis of covariance structures. Psychological bulletin, $88(3), 588$.

Bettayeb, H., Alshurideh, M. T., \& Al Kurdi, B. (2020). The effectiveness of Mobile Learning in UAE Universities: A systematic review of Motivation, Self-efficacy, Usability and Usefulness. International Journal of Control and Automation, 13(2), 1558-1579.

Bhattacherjee, A. (2001). Understanding information systems continuance: An expectation-confirmation model. MIS quarterly, 25(3), 351370.

Bhattacherjee, A., \& Hikmet, N. (2007). Physicians' resistance toward healthcare information technology: a theoretical model and empirical test. European Journal of Information Systems, 16(6), 725-737.

Brown, S. A., \& Venkatesh, V. (2005). Model of adoption of technology in households: A baseline model test and extension incorporating household life cycle. MIS quarterly, 29(3), 399-426.

Mac Callum, K., \& Jeffrey, L. (2014). Comparing the role of ICT literacy and anxiety in the adoption of mobile learning. Computers in Human Behavior, 39, 8-19.

Chen, E., \& Li, Z. (2011, July). On the application of multimedia technology in foreign language teaching and learning in China's colleges: Challenges, problems and implications. In 2011 International Conference on Multimedia Technology (pp. 595-597). IEEE.

Cheon, J., Lee, S., Crooks, S. M., \& Song, J. (2012). An investigation of mobile learning readiness in higher education based on the theory of planned behavior. Computers \& education, 59(3), 1054-1064.

Davis, F. D. (1989). Perceived usefulness, perceived ease of use, and user acceptance of information technology. MIS quarterly, 13(3), 319340.

Davis, F. D., Bagozzi, R. P., \& Warshaw, P. R. (1992). Extrinsic and intrinsic motivation to use computers in the workplace. Journal of applied social psychology, 22(14), 1111-1132.

Dijkstra, T. K., \& Henseler, J. (2015). Consistent and asymptotically normal PLS estimators for linear structural equations. Computational Statistics \& Data Analysis, 81, 10-23.

Distler, V., Lallemand, C., \& Koenig, V. (2020). How acceptable is this? How user experience factors can broaden our understanding of the acceptance of privacy trade-offs. Computers in Human Behavior, 106, 106227.

Doll, W. J., Hendrickson, A., \& Deng, X. (1998). Using Davis's perceived usefulness and ease-of-use instruments for decision making: a confirmatory and multigroup invariance analysis. Decision Sciences, 29(4), 839-869.

El-Gayar, O., Moran, M., \& Hawkes, M. (2011). Students' acceptance of tablet PCs and implications for educational institutions. Journal of Educational Technology \& Society, 14(2), 58-70.

Elbasir, M., Elareshi, M., Habas, M., Jeljeli, R., \& Salloum, S. A. (2021, June). Media and Non-media Students' Feedback and Improvement of University Teaching and the Learning Environment. In The International Conference on Artificial Intelligence and Computer Vision (pp. 754-765). Springer, Cham.

Ellahi, A. (2017, December). Fear of using technology: Investigating impact of using social networking sites in business education. In 2017 IEEE 15th student Conference on research and development (SCOReD) (pp. 234-237). IEEE.

Fishbein, M., \& Ajzen, I. (1977). Belief, attitude, intention, and behavior: An introduction to theory and research

Fornell, C., \& Larcker, D. F. (1981). Evaluating structural equation models with unobservable variables and measurement error. Journal of Marketing Research, 18(1), 39-50.

Gaid, M. L., \& Salloum, S. A. (2021, June). Explore the Relationship Between COVID-19 Testing Rates with the Number of Cases. In The International Conference on Artificial Intelligence and Computer Vision (pp. 33-45). Springer, Cham.

Gasaymeh, A. M. M., \& Waswas, D. M. (2019). The use of TAM to investigate university students' acceptance of the formal use of smartphones for learning: a qualitative approach. International Journal of Technology Enhanced Learning, 11(2), 136-156.

Gerhold, L. (2020). COVID-19: Risk Perception and Coping Strategies.

Goodhue, D. L., Lewis, W., \& Thompson, R. (2012). Does PLS have advantages for small sample size or non-normal data?. MIS quarterly, $36(3), 981-1001$. 
Gresham, J. (2020). Manufacturing trends in automated inspection equipment: Linking technology with business change management using the technology acceptance model (Doctoral dissertation, Northcentral University).

Habes, M., Salloum, S. A., Elareshi, M., Ganji, S. F. G., Ziani, A. K., \& Elbasir, M. (2020, December). The Influence of YouTube Videos on ELA During the COVID-19 Outbreaks in Jordan. In 2020 Sixth International Conference on e-Learning (econf) (pp. 133-138). IEEE.

Habes, M., Salloum, S. A., Alghizzawi, M., \& Mhamdi, C. (2019, October). The relation between social media and students' academic performance in Jordan: YouTube perspective. In International Conference on Advanced Intelligent Systems and Informatics (pp. 382392). Springer, Cham.

Hair, J. F., Ringle, C. M., \& Sarstedt, M. (2011). PLS-SEM: Indeed a silver bullet. Journal of Marketing theory and Practice, 19(2), 139152.

Hair, J., Hollingsworth, C. L., Randolph, A. B., \& Chong, A. Y. L. (2017). An updated and expanded assessment of PLS-SEM in information systems research. Industrial Management \& Data Systems, 117(3): 442-58.

Hair Jr, J. F., Hult, G. T. M., Ringle, C., \& Sarstedt, M. (2016). A primer on partial least squares structural equation modeling (PLS-SEM). Sage publications.

Hantoobi, S., Wahdan, A., Salloum, S.A., \& Shaalan, K. (2021). Integration of Knowledge Management in a Virtual Learning Environment: A Systematic Review. Recent Advances in Technology Acceptance Models and Theories, 247-72.

Henseler, J., Dijkstra, T. K., Sarstedt, M., Ringle, C. M., Diamantopoulos, A., Straub, D. W., ... \& Calantone, R. J. (2014). Common beliefs and reality about PLS: Comments on Rönkkö and Evermann (2013). Organizational research methods, 17(2), 182-209.

Henseler, J., Ringle, C. M., \& Sarstedt, M. (2015). A new criterion for assessing discriminant validity in variance-based structural equation modeling. Journal of the academy of marketing science, 43(1), 115-135.

Henseler, J., Ringle, C. M., \& Sinkovics, R. R. (2009). The use of partial least squares path modeling in international marketing. In New challenges to international marketing, 20,277-319.

Hu, L. T., \& Bentler, P. M. (1998). Fit indices in covariance structure modeling: Sensitivity to underparameterized model misspecification. Psychological methods, 3(4), 424.

Huang, F., Teo, T., \& Zhou, M. (2020). Chinese students' intentions to use the Internet-based technology for learning. Educational Technology Research and Development, 68(1), 575-591.

Johnston, A. C., \& Warkentin, M. (2010). Fear appeals and information security behaviors: An empirical study. MIS quarterly, 34(3), 549566.

Joo, Y. J., Kim, N., \& Kim, N. H. (2016). Factors predicting online university students' use of a mobile learning management system (mLMS). Educational Technology Research and Development, 64(4), 611-630.

Kamal, S. A., Shafiq, M., \& Kakria, P. (2020). Investigating acceptance of telemedicine services through an extended technology acceptance model (TAM). Technology in Society, 60, 101212.

Karjaluoto, H., Mattila, M., \& Pento, T. (2002). Factors underlying attitude formation towards online banking in Finland. International journal of bank marketing, 20(6), 261-72.

Khanh, N. T. V., \& Gim, G. (2014). Factors Influencing Mobile-Learning Adoption Intention: An Empirical Investigation in High Education. Journal of Social Sciences, 10(2), 51-62.

Al Khasawneh, M., Abuhashesh, M., Ahmad, A., Masa'deh, R., \& Alshurideh, M. T. (2021). Customers Online Engagement with Social Media Influencers' Content Related to COVID 19. The Effect of Coronavirus Disease (COVID-19) on Business Intelligence, $334,385$.

Kim, B. (2010). An empirical investigation of mobile data service continuance: Incorporating the theory of planned behavior into the expectation-confirmation model. Expert systems with applications, 37(10), 7033-7039.

Kline, R. B. (2015). Principles and practice of structural equation modeling. Guilford publications.

Krejcie, R. V., \& Morgan, D. W. (1970). Determining sample size for research activities. Educational and Psychological Measurement, 30(3), 607-610.

Al Kurdi, B., Alshurideh, M., Salloum, S., Obeidat, Z., \& Al-dweeri, R. (2020). An empirical investigation into examination of factors influencing university students' behavior towards elearning acceptance using SEM approach. International Journal of Interactive Mobile Technologies (iJIM) 14(02), 19-41.

- (2021). The Effects of Subjective Norm on the Intention to Use Social Media Networks: An Exploratory Study Using PLS-SEM and Machine Learning Approach. In Advanced Machine Learning Technologies and Applications: Proceedings of AMLTA 2021, Springer International Publishing, 581-92.

Al Kurdi, B., Alshurideh, M., \& Salloum, S. A. (2020). Investigating a theoretical framework for e-learning technology acceptance. International Journal of Electrical and Computer Engineering (IJECE), 10(6), 6484-6496.

Le, T. T., Pham, H. M., Chu, N. H., Nguyen, D. K., \& Ngo, H. M. (2020). Factors affecting users' continuance intention towards mobile banking In Vietnam. American Journal of Multidisciplinary Research \& Development (AJMRD), 2(4), 42-51.

Leo, S., Alsharari, N. M., Abbas, J., \& Alshurideh, M. T. (2021). From Offline to Online Learning: A Qualitative Study of Challenges and Opportunities as a Response to the COVID-19 Pandemic in the UAE Higher Education Context. The Effect of Coronavirus Disease (COVID-19) on Business Intelligence, 334, 203.

Li, L., Chen, Y., Li, Z., Li, D., Li, F., \& Huang, H. (2018, August). Online virtual experiment teaching platform for database technology and application. In 2018 13th International Conference on Computer Science \& Education (ICCSE) (pp. 1-5). IEEE.

Liang, Y., Zheng, T., \& Wang, M. (2011, July). English audio-visual teaching mode and its teaching environment construction-Henan institute of science and technology as the example. In 2011 International Conference on Multimedia Technology (pp. 3050-3053). IEEE.

Lin, C. Y. (2020). Social reaction toward the 2019 novel coronavirus (COVID-19). Social Health and Behavior, 3(1), 1.

Liu, C. Z., Au, Y. A., \& Choi, H. S. (2014). Effects of freemium strategy in the mobile app market: An empirical study of google play. Journal of Management Information Systems, 31(3), 326-354.

Liu, Q., Geertshuis, S., \& Grainger, R. (2020). Understanding academics' adoption of learning technologies: A systematic review. Computers \& Education, 151, 103857.

Liu, S. H., Liao, H. L., \& Peng, C. J. (2005). Applying the technology acceptance model and flow theory to online e-learning users' acceptance behavior. E-learning, 4(H6), H8.

Liu, Y., \& Chen, N.S. (2008). An Adoption Model for Mobile Learning. In Proceeding for the IADIS International Conference E-Commerce, 251-56.

Lohmöller, J. B. (2013). Latent variable path modeling with partial least squares. Springer Science \& Business Media. 
Machů, E., \& Morysová, D. (2016). Analysis of the emotion of fear in gifted children and its use in teaching practice. Procedia-Social and Behavioral Sciences, 217, 222-228.

Makttoofa, N., Khalidb, H., \& Abdullahc, I. (2020). The effect of individual factors on the adoption of mobile banking within banks in Iraq. International Journal of Innovation, Creativity and Change, 11(9), 73-90.

Mcllroy, S., Ali, N., \& Hassan, A. E. (2016). Fresh apps: an empirical study of frequently-updated mobile apps in the Google play store. Empirical Software Engineering, 21(3), 1346-1370.

Al Mehrez, A. A., Alshurideh, M., Al Kurdi, B., \& Salloum, S. A. (2020, October). Internal Factors Affect Knowledge Management and Firm Performance: A Systematic Review. In International Conference on Advanced Intelligent Systems and Informatics (pp. 632-643). Springer, Cham.

Meng, F., Guo, X., Zhang, X., Peng, Z., \& Lai, K. H. (2020, January). Examining the role of technology anxiety and health anxiety on elderly users' continuance intention for mobile health services use. In Proceedings of the 53rd Hawaii International Conference on System Sciences.

Mhamdi, C., Al-Emran, M., \& Salloum, S. A. (2018). Text mining and analytics: A case study from news channels posts on Facebook. In Intelligent Natural Language Processing: Trends and Applications (pp. 399-415). Springer, Cham.

Alsharari, N. M., \& Alshurideh, M. T. (2020). Student retention in higher education: the role of creativity, emotional intelligence and learner autonomy. International Journal of Educational Management,

35(1), 233-47. https://doi.org/10.1108/IJEM-12-2019-0421.

Mohammadi, H. (2015). Social and individual antecedents of m-learning adoption in Iran. Computers in Human Behavior, 49, 191-207.

MORCHID, N. The Current State of Technology Acceptance: A Comparative Study.

MOUZAEK, E., ALAALI, N., A SALlOUM, S. A. I. D., \& ABURAYYA, A. (2021). An Empirical Investigation of the Impact of Service Quality Dimensions on Guests Satisfaction: A Case Study of Dubai Hotels. Journal of Contemporary Issues in Business and Government, 27(3), 1186-1199.

Mtebe, J., \& Raisamo, R. (2014). Investigating students' behavioural intention to adopt and use mobile learning in higher education in East Africa. International Journal of Education and Development using ICT, 10(3).

Naqvi, R., Soomro, T. R., Alzoubi, H. M., Ghazal, T. M., \& Alshurideh, M. T. (2021, June). The Nexus Between Big Data and DecisionMaking: A Study of Big Data Techniques and Technologies. In The International Conference on Artificial Intelligence and Computer Vision (pp. 838-853). Springer, Cham, 838-53.

Nascimento, B., Oliveira, T., \& Tam, C. (2018). Wearable technology: What explains continuance intention in smartwatches?. Journal of Retailing and Consumer Services, 43, 157-169.

Nchunge, D. M., Sakwa, M., \& Mwangi, W. (2012). User's perception on ICT adoption for education support in schools: a survey of secondary school teacher's in Thika district Kenya. International Journal of Humanities and Social Science, 2(10), 17-29.

Nunnally, J. C. (1994). Psychometric theory 3E. Tata McGraw-hill education.

Nunnally, J. C. (1978). Psychometric theory (2nd edit.). New York.

Nuseir, M. T., Al Kurdi, B.H., Alshurideh, M.T., \& Alzoubi, H.M. (2021). Gender Discrimination at Workplace: Do Artificial Intelligence (AI) and Machine Learning (ML) Have Opinions About It. In The International Conference on Artificial Intelligence and Computer Vision, Springer, 301-16.

Pappas, G., Kiriaze, I. J., Giannakis, P., \& Falagas, M. E. (2009). Psychosocial consequences of infectious diseases. Clinical microbiology and infection, 15(8), 743-747.

Park, S. Y., Nam, M. W., \& Cha, S. B. (2012). University students' behavioral intention to use mobile learning: Evaluating the technology acceptance model. British journal of educational technology, 43(4), 592-605.

Podsakoff, P. M., MacKenzie, S. B., Lee, J. Y., \& Podsakoff, N. P. (2003). Common method biases in behavioral research: a critical review of the literature and recommended remedies. Journal of applied psychology, 88(5), 879.

Prieto, J. C. S., Migueláñez, S. O., \& García-Peñalvo, F. J. (2014, October). Mobile learning adoption from informal into formal: an extended TAM model to measure mobile acceptance among teachers. In Proceedings of the Second International Conference on Technological Ecosystems for Enhancing Multiculturality (pp. 595-602).

Raza, S. A., Qazi, W., Khan, K. A., \& Salam, J. (2021). Social isolation and acceptance of the learning management system (LMS) in the time of COVID-19 pandemic: an expansion of the UTAUT model. Journal of Educational Computing Research, 59(2), 183-208.

Ringle, C. M., Wende, S., \& Becker, J.M.. (2015). SmartPLS 3. Bönningstedt: SmartPLS.

Salloum, S. A., Al-Emran, M., Khalaf, R., Habes, M., \& Shaalan, K. (2019). An Innovative Study of E-Payment Systems Adoption in Higher Education: Theoretical Constructs and Empirical Analysis. International Journal of Interactive Mobile Technologies, 13(6).

Salloum, S. A., Al-Emran, M., Abdallah, S., \& Shaalan, K. (2017, September). Analyzing the Arab gulf newspapers using text mining techniques. In International Conference on Advanced Intelligent Systems and Informatics (pp. 396-405). Springer, Cham.

Salloum, S. A., Al-Emran, M., \& Shaalan, K. (2016). A survey of lexical functional grammar in the Arabic context. International Journal of Computing and Network Technology, 4(03).

Salloum, S. A., Maqableh, W., Mhamdi, C., Al Kurdi, B., \& Shaalan, K. (2018). Studying the social media adoption by university students in the United Arab Emirates. International Journal of Information Technology and Language Studies, 2(3), 83-95.

Salloum, S. A., Al-Emran, M., Habes, M., Alghizzawi, M., Ghani, M. A., \& Shaalan, K. (2021). What Impacts the Acceptance of E-learning Through Social Media? An Empirical Study. Recent Advances in Technology Acceptance Models and Theories, 419-431.

. (2021). Predicting the Intention to Use Social Media Sites: A Hybrid SEM-Machine Learning Approach. Advanced Machine Learning Technologies and Applications: Proceedings of AMLTA 2021: 324.

Salloum, S. A., \& Al-Emran, M. (2018). Factors affecting the adoption of E-payment systems by university students: Extending the TAM with trust. International Journal of Electronic Business, 14(4), 371-390.

Salloum, S. A., Alshurideh, M., Elnagar, A., \& Shaalan, K. (2020, April). Machine learning and deep learning techniques for cybersecurity: a review. In Joint European-US Workshop on Applications of Invariance in Computer Vision (pp. 50-57). Springer, Cham, 50-57.

Salloum, S. A., Mhamdi, C., Al Kurdi, B., \& Shaalan, K. (2018). Factors affecting the adoption and meaningful use of social media: a structural equation modeling approach. International Journal of Information Technology and Language Studies, 2(3), 96-109.

Sami Alkalha, Ziad et al. (2012). European Journal of Economics, Finance and Administrative Sciences Investigating the Effects of Human Resource Policies on Organizational Performance: An Empirical Study on Commercial Banks Operating in Jordan. 
Song, Y., \& Kong, S. C. (2017). Investigating students' acceptance of a statistics learning platform using technology acceptance model. Journal of Educational Computing Research, 55(6), 865-897.

Suleman, M., Soomro, T. R., Ghazal, T. M., \& Alshurideh, M. (2021, June). Combating Against Potentially Harmful Mobile Apps. In The International Conference on Artificial Intelligence and Computer Vision (pp. 154-173). Springer, Cham.

Sultan, R. A., Alqallaf, A. K., Alzarooni, S. A., Alrahma, N. H., AlAli, M. A., \& Alshurideh, M. T. (2021, June). How Students Influence Faculty Satisfaction with Online Courses and Do the Age of Faculty Matter. In The International Conference on Artificial Intelligence and Computer Vision (pp. 823-837). Springer, Cham.

Al Suwaidi, F., Alshurideh, M., Al Kurdi, B., \& Salloum, S. A. (2020, October). The impact of innovation management in SMEs performance: A systematic review. In International Conference on Advanced Intelligent Systems and Informatics (pp. 720-730). Springer, Cham.

Tam, C., Santos, D., \& Oliveira, T. (2020). Exploring the influential factors of continuance intention to use mobile Apps: Extending the expectation confirmation model. Information Systems Frontiers, 22(1), 243-257.

Tarhini, A., Hone, K., \& Liu, X. (2015). A cross-cultural examination of the impact of social, organisational and individual factors on educational technology acceptance between B ritish and L ebanese university students. British Journal of Educational Technology, 46(4), 739-755.

Teo, T. (2012). Examining the intention to use technology among pre-service teachers: An integration of the technology acceptance model and theory of planned behavior. Interactive Learning Environments, 20(1), 3-18.

Thatcher, J. B., \& Perrewe, P. L. (2002). An empirical examination of individual traits as antecedents to computer anxiety and computer self-efficacy. MIS quarterly, 26(4), 381-396.

Trial, D. "Model Fit." https://www.smartpls.com/documentation/algorithms-and-techniques/model-fit.

Tsai, T. H., Lin, W. Y., Chang, Y. S., Chang, P. C., \& Lee, M. Y. (2020). Technology anxiety and resistance to change behavioral study of a wearable cardiac warming system using an extended TAM for older adults. PloS one, 15(1), e0227270.

Urbach, N., \& Ahlemann, F. (2010). Structural equation modeling in information systems research using partial least squares. Journal of Information technology theory and application, 11(2), 5-40.

Venkatesh, V., \& Bala, H. (2008). Technology acceptance model 3 and a research agenda on interventions. Decision sciences, 39(2), 273315.

Venkatesh, V., \& Bala, H. (2008). Technology acceptance model 3 and a research agenda on interventions. Decision sciences, 39(2), 273315.

Venkatesh, V., Morris, M. G., Davis, G. B., \& Davis, F. D. (2003). User acceptance of information technology: Toward a unified view. MIS Quarterly, 27(3), 425-478.

Wong, K. T., Teo, T., \& Russo, S. (2012). Influence of gender and computer teaching efficacy on computer acceptance among Malaysian student teachers: An extended technology acceptance model. Australasian Journal of Educational Technology, 28(7).

Zhang, S. X., Wang, Y., Rauch, A., \& Wei, F. (2020). Unprecedented disruption of lives and work: Health, distress and life satisfaction of working adults in China one month into the COVID-19 outbreak. Psychiatry research, 288, 112958

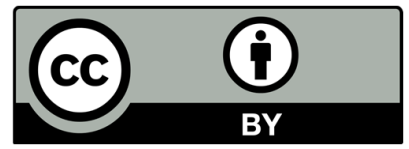

(C) 2021 by the authors; licensee Growing Science, Canada. This is an open access article distributed under the terms and conditions of the Creative Commons Attribution (CC-BY) license (http://creativecommons.org/licenses/by/4.0/). 